\title{
Performance, Trends and Innovations in the Current Trade Sector Context
}

\author{
Ioan BIRCEA \\ University of Medicine, Pharmacy, Sciences and Technology of Targu Mures, Romania \\ e-mail address: ioan_bircea@yahoo.com \\ Kinga Emese ZSIDO \\ University of Medicine, Pharmacy, Sciences and Technology of Targu Mures, Romania \\ e-mail address: kinga.zsido@gmail.com
}

\begin{abstract}
The commercial sector and especially the food trade in Romania have expanded more and more through the medium of hypermarkets-supermarkets, online commerce, etc. thus dominating the market. The turnover and profit they make are significantly increasing, while small and medium-sized businesses in stores and traditional stores lose customers, their market share is diminishing, profitability is low, and they are confronted with big financial problems. Modern trade tends represent almost $60 \%$ of Romania's total market, which means that small shops are losing ground in detriment of others, despite their currently large number at national level. The study, extended over a period of more than 5 years, includes a comparative analysis of the small and medium-sized enterprises in the food commerce sector of Cluj County and the supermarkets-hypermarkets in Romania. Advantages of hypermarkets - supermarkets, online commerce, etc. in relation to small and medium-sized stores are ultimately reflected in the financial performance. Following the selection of 5 financial indicators, considered by the authors to be representative of the trade sector, and their comparative analysis, one can see the economic and financial situation these small and medium retail companies are facing, if they do not change their strategy. Their disappearance from the Romanian market would result in social and economic consequences and the discontent of a segment of the population.
\end{abstract}

Keywords: financial performance, food trade sector, hypermarkets, traditional smaller shops

\section{Introduction}

In recent decades, the trade sector, both nationally and internationally, has undergone major changes. Thus, we are witnessing an expansion of the market share of supermarkets hypermarkets and online commerce, in the detriment of traditional retail companies, and the trend continues. According to the Financial Journal in Romania, this type of trade reaches a share of 60\%, while in countries such as Hungary, Croatia, Czech Republic, Austria it is situated between $72 \%-76 \%$ and in Slovakia it reaches $81 \%$. Percentages are lower in Eastern Europe, since the interest of the consumers towards traditional shops in these countries is still high (FENYVES, 2016).

As early as 2004, Peter Drucker has stated that "over time, e-commerce will take out multinational and traditional companies." In 2017, online sales in Romania were estimated at 2.8 billion euro, a 40\% increase compared to 2016, and in 2016 a 38\% increase compared to 2015, much higher than the European level of only 15\%, or 530 billion Euro (Romanian Online Shops Association in Romania, 2017, GPeC, 2018).

These high sales are explained by the advantages offered by hypermarkets, supermarkets and online stores compared to traditional stores: 
- good price - quality ratio. Since 1930, this theory has been put into practice by Michael Cullen (Halper, 1979);

- granted discounts;

- a much more diversified range of products;

- a rigorous control of food products;

- own production laboratories, some within the store, for products such as pastry, bakery and meat products;

- time savings for the buyer through a large number of cash registers;

- wide spaces with direct access to the goods;

- the possibility of returning products;

- children's playgrounds, etc.

Another way of increasing sales by the big retail chains is through actions of interest and social responsibility (in 2016, only Kaufland Romania invested an amount of 26 million lei in projects for the local community, $13 \%$ more than in 2015), through some charity and environmental actions, etc.

All these measures, in conjunction with the increase in the Romanian population's income and in the investments made by the large retail chains, led to the increase of the turnover in the retail trade (except for the trade in motor vehicles and motorcycles) at national level. Thus, there was an increase of $10.8 \%$ in 2017 compared to 2016, and of 13.5\% in 2016 compared to 2015 (gross series), a much higher growth compared to that of the previous year, which was of $8.3 \%$ (Figure 1 ).

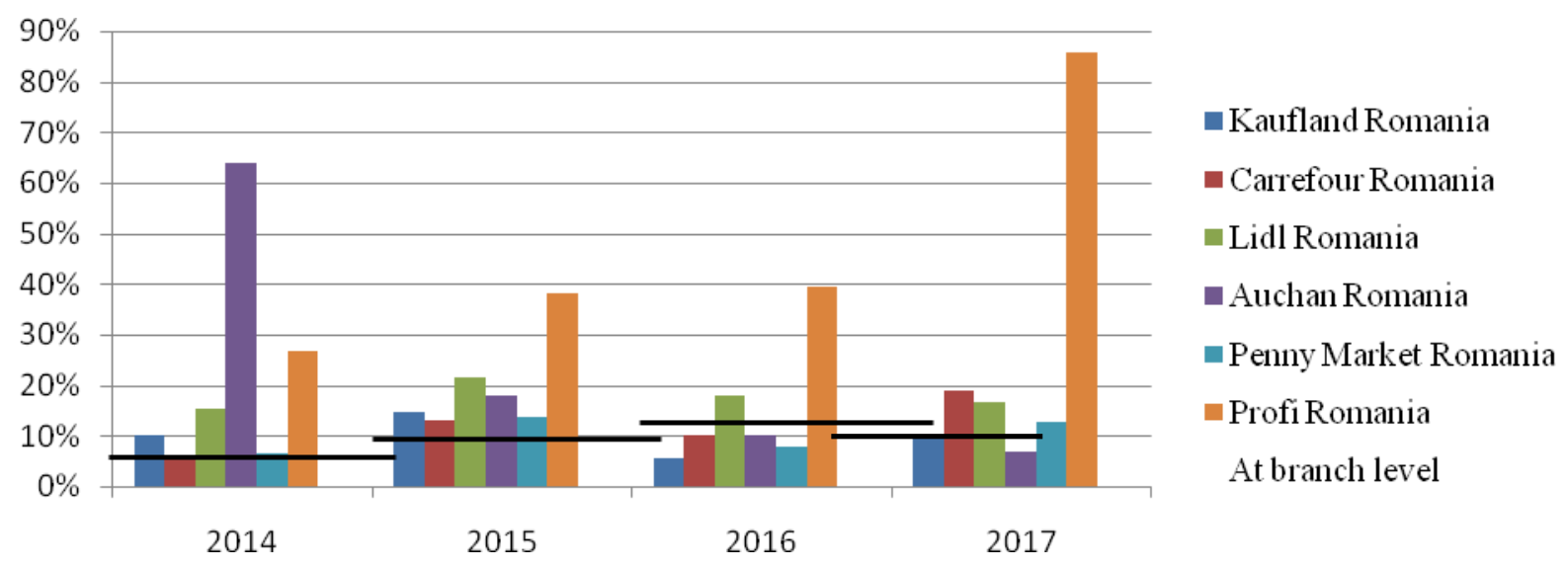

Figure 1-The annual growth rate of turnover in supermarkets-hypermarkets and at the sector level

Source : authors' own research

In the case of food products trade, we observe a trend of increasing sales growth (except for 2013), most likely due to the drop in value added tax (Table no.1). 
Table 1. Indices of retail, by group of goods

Previous year $\mathbf{= 1 0 0}$

\begin{tabular}{|l|l|l|l|l|l|l|l|}
\hline CAEN & $\mathbf{2 0 1 0}$ & $\mathbf{2 0 1 1}$ & $\mathbf{2 0 1 2}$ & $\mathbf{2 0 1 3}$ & $\mathbf{2 0 1 4}$ & $\mathbf{2 0 1 5}$ & $\mathbf{2 0 1 6}$ \\
\hline Food products (\%) & 90,6 & 93,1 & 102,6 & 99,9 & 105,3 & 119,1 & 113,7 \\
\hline $\begin{array}{l}\text { Non -food } \\
\text { products(\%) }\end{array}$ & 89,3 & 104,4 & 104,1 & 103,6 & 110,8 & 102,8 & 115,2 \\
\hline $\begin{array}{l}\text { Retail commerce of } \\
\text { fuels (\%) }\end{array}$ & 103,3 & 98,4 & 106,2 & 96,4 & 100,3 & 105,8 & 110,2 \\
\hline TOTAL (\%) & 93,0 & 98,8 & 104,1 & 100,5 & 106,4 & 108,9 & 113,5 \\
\hline
\end{tabular}

Table 2. The link between gross salary and income from food trade

\begin{tabular}{|l|l|l|l|l|l|l|l|l|}
\hline & $\mathbf{2 0 1 0}$ & $\mathbf{2 0 1 1}$ & $\mathbf{2 0 1 2}$ & $\mathbf{2 0 1 3}$ & $\mathbf{2 0 1 4}$ & $\mathbf{2 0 1 5}$ & $\mathbf{2 0 1 6}$ & $\mathbf{2 0 1 7}$ \\
\hline Average salary (euro) & 452,9 & 468,1 & 463,6 & 490,5 & 524,3 & 575,5 & 624,2 & 700,7 \\
\hline $\begin{array}{l}\text { Sales at national level } \\
\text { in retail (millon euro) }\end{array}$ & 9802 & 10293 & 10517 & 11100 & 11892 & 13659 & 14936 & 16113 \\
\hline correlation coefficient & 0,99 & & & & & & & \\
\hline The determination coefficient & 0,98 & & & & & & & \\
\hline
\end{tabular}

Source - National Institute of Statistics (INSSE)

The importance of the national trade sector is reflected both in its contribution to GDP and added value, as well as by ensuring wage income for a significant share of the population. According to INSSE, in 2017, GDP grew by 7\% compared to 2016 (the largest contributor being the industry sector), of which a 1.6\% increase was provided by the trade sector, its contribution to GDP formation being of $18.7 \%$ [INSSE Press Release]. Also, according to the statistical data provided by INSSE, the share of active commercial enterprises in the total of active enterprises (527792 in 2016) in the last three years is 32\% on average, and among them "Retail trade excluding motor vehicles and motorcycles" represents 20-21\%. Thus, out of 5,223,767 countrywide employees (in 2016), over 17\% are employed in the commerce sector and $10 \%$ of them are employed in the "Retail trade excluding motor vehicles and motorcycles".

Accordingly, the following questions arise:

- How can smaller stores and traditional shops survive?

- What are the signals for a small store that it needs to change strategy to survive?

In order to answer these questions, we conducted a comparative analysis, based on financial indicators, between small and medium-sized retail companies and hypermarkets supermarkets. As a reference, we have appealed in some cases to the same industry-wide indicators.

\section{Methodology}

The study that was carried out included enterprises headquartered in Cluj county (Romania), with the main activity of "Retail commerce in non-specialized stores with mainly food products". Thus, the database consists of data presented in the Financial Statements of these enterprises for 5 consecutive years (2011-2015) and submitted to the authors by the Regional Public Finance Regional Directorate Cluj-Napoca (DGRFP Cluj Napoca). Out of these companies, many have been eliminated due to their bankruptcy, 
leaving 1,020 companies with complete financial statements. An additional database of supermarkets and hypermarkets in Romania was created by the authors based on financial reports to the Ministry of Finance. For National References, some indicators were taken from the National Institute of Statistics (INSSE).

In the data analysis we used the SPSS program and the Excel (Analysis Tool Pak) extension. As for large series of data, as well as a 5-year extended period, in the study we focused on the averages of homogeneous groups in the studied collectivity (clusters). Collectivity grouping was performed using the non-hierarchical method, the K-means method (Kmeans).

Based on factorial analysis (ANOVA), out of a group of financial indicators as turnover/ square meter, net margin, stock turnover rate, increase in business turnover, average stock, economic profitability, etc. [Nicasio, 2016] and non-financial indicators (number of customers, customer-buy-in customers report, etc.) [DWBI Expert Inc., 2015], the authors selected five financial indicators considered representative of the studied field. The authors and other specialists (Capece et al, 2007; Gordon, 2016) consider that there are sufficient signals in estimating the present and the subsequent situation from the information which results from the analysis of these financial indicators.

\section{Results and discussions}

An advantage of hypermarkets-supermarkets in relation to small shops is the investments made by them in recent years. The land, buildings and parking facilities ensure the possibility of selling a wide assortment of products, direct access to goods, playgrounds for children etc., all of which explain to some extent the high sales volume. To support this statement, we have studied statistically the link between the sales of hypermarketssupermarkets in Romania and the investments made by them.

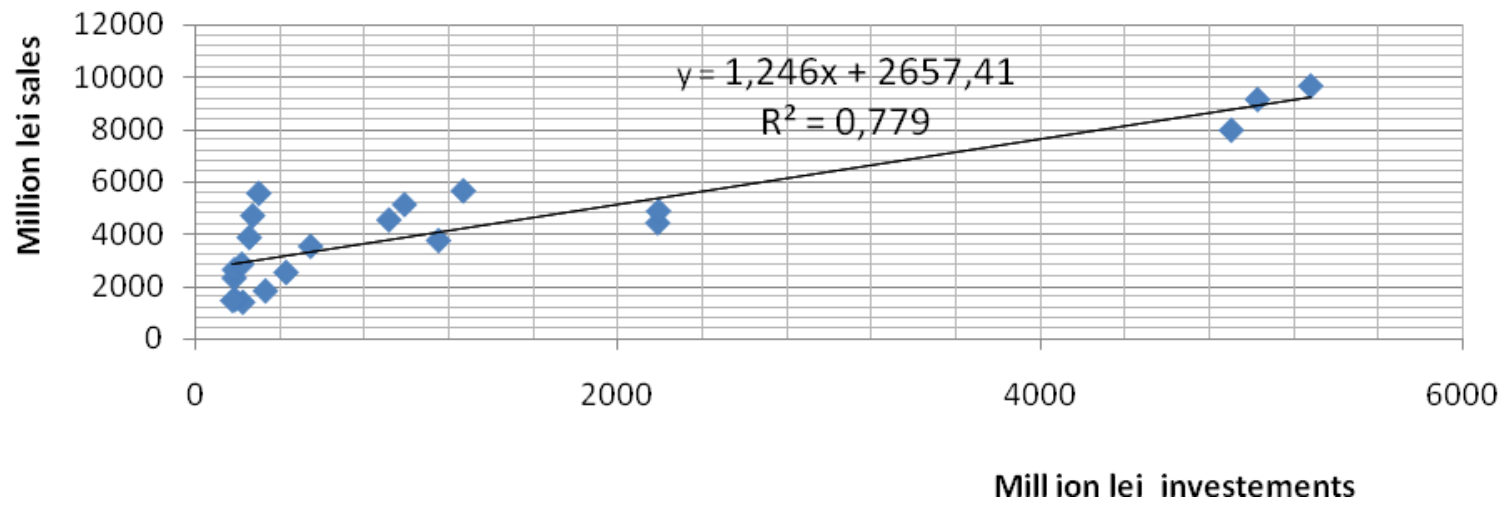

Figure 2- The link between investment and sales in the case of supermarkets in Romania Source : authors' own research

The value of the determination coefficient (0.78) certifies that investments are a decisive factor in sales made in supermarkets (Figure 3). According to the regression equation $(\beta=$ 1.24), for supermarkets studied in Romania, it results that 1 leu invested in these companies generates a sale of 1.24 lei. 
Table3. ANOVA

\begin{tabular}{|l|l|l|l|l|l|}
\hline & df & SS & MS & F & Significance F \\
\hline Regression & 1 & 89041362,05 & 89041362 & 67,26603632 & $1,15579 \mathrm{E}-07$ \\
\hline Residual & 19 & 25150669,9 & 1323719 & & \\
\hline Total & 20 & 114192032 & & & \\
\hline
\end{tabular}

A further check was carried out through the $\mathrm{F}$ test $(\mathrm{Fcal}=67>$ Ftabel $=4.3)$, according to which the investment variable exerts a significant influence on turnover (Table 3 ANOVA).

The investments that are made will change the composition of the assets. In the case of supermarkets, by analyzing their composition over the 2011-2016 period, we found out how heterogeneous it is. Thus, the share of total active investments in some hypermarkets over the review period is significant (Kaufland 80\%, Auchan 60\%) or less significant (Carrefour 40\%, Penny 32\%).

To find out: - whether the offer is tailored to the request; - whether the implemented promotion methods are effective, - the appropriate exposure of the goods on the shelf, etc. we have opted for an indicator that correlates the sales level with the stock level (average stock/turnover).

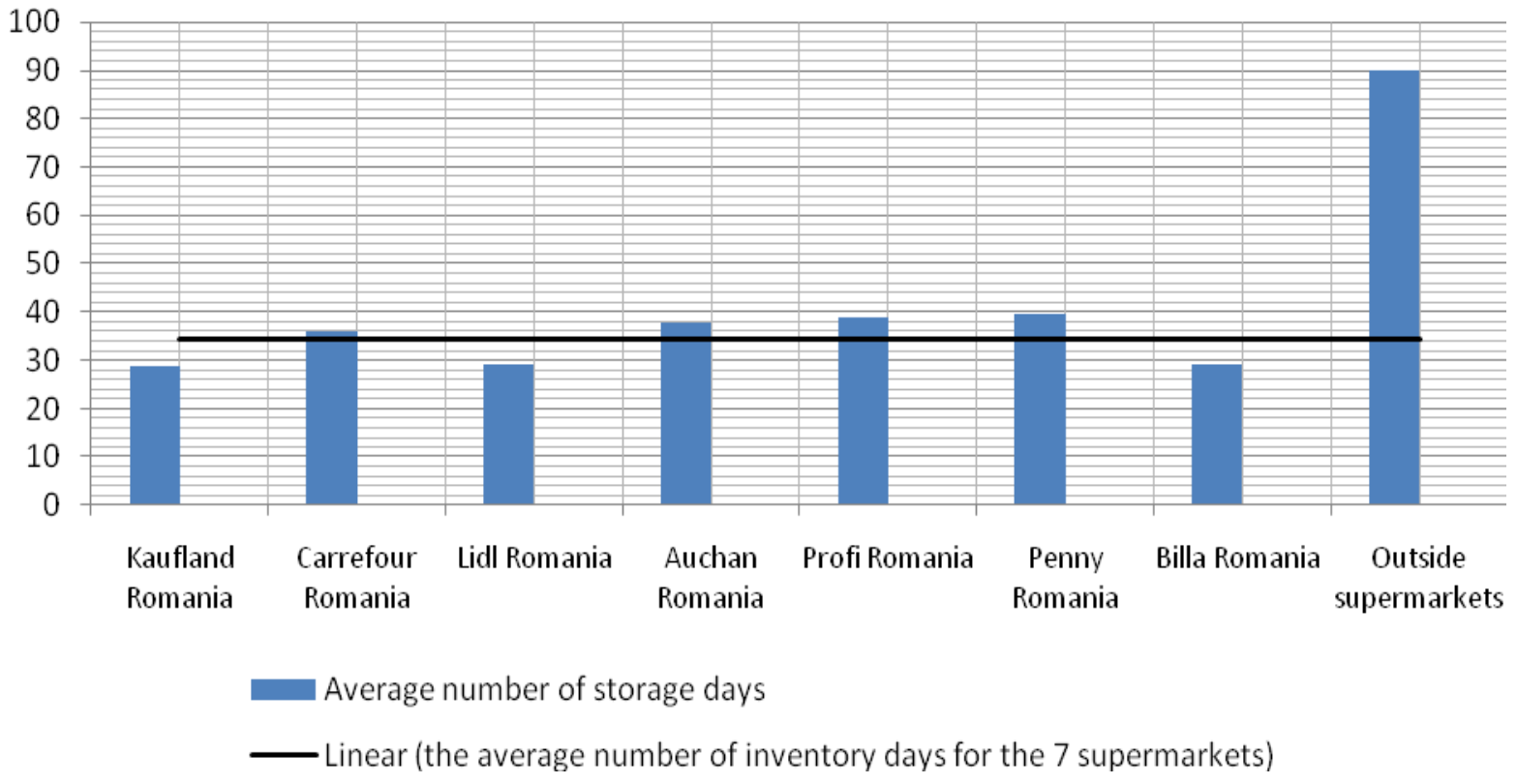

Figure 3. Average number of storage days in period 2013-2017 (days)

Source : authors' own research

The number of average storage days for the supermarkets is 30 days, that is, one month. In the case of the Cluj County units (649 in 2015 and 793 stores in 2011), about $80 \%$ of the collectivity have a stock turnover rate between 3 and 4 rotations / year, that is, an average stationary period of 90 days, three times the storage period in hypermarkets. Of course, this low inventory turnover will have direct effects on both stock, sales volume and economic and financial profitability. 
But, according to the study, we find that a small group of stores (their frequency is below 18\%) have a higher inventory turnover than supermarkets (Cluster 2). The last two clusters, 4 and 5, contain a small number of stores where the level of this indicator is very high (over 150 turnovers). From a statistical viewpoint, the number of these companies ( 4 and 5 companies) with such a high number of turnovers is not representative for the studied collectivity.

Table 4. Statistical characteristics of the stock rotational speed indicator, for the entire collectivity and for groups

\begin{tabular}{|c|c|c|c|c|c|c|}
\hline Groups & $\begin{array}{l}\text { Statistical } \\
\text { indicator }\end{array}$ & 2011 & 2012 & 2013 & 2014 & 2015 \\
\hline $\begin{array}{l}\text { Number and } \\
\text { removed fron }\end{array}$ & $\begin{array}{l}\text { weight of units } \\
\text { analysis }\end{array}$ & $\begin{array}{l}227 \\
22,25 \%\end{array}$ & $\begin{array}{l}254 \\
24,90 \%\end{array}$ & $\begin{array}{l}289 \\
28,33 \%\end{array}$ & $\begin{array}{l}326 \\
31,96 \%\end{array}$ & $\begin{array}{l}371 \\
36,37 \%\end{array}$ \\
\hline $\begin{array}{l}\text { Entire } \\
\text { collectivity }\end{array}$ & $\begin{array}{l}\text { Average } \\
\text { Coefficient of } \\
\text { variation } \\
\text { No units }\end{array}$ & $\begin{array}{l}11,70 \\
20,92 \\
178,80 \% \\
793\end{array}$ & $\begin{array}{l}12,16 \\
27,31 \\
224,58 \% \\
766\end{array}$ & $\begin{array}{l}10,72 \\
23,24 \\
216,79 \% \\
731\end{array}$ & $\begin{array}{l}10,63 \\
24,01 \\
225,87 \% \\
694\end{array}$ & $\begin{array}{l}13,40 \\
28,37 \\
211,71 \% \\
649\end{array}$ \\
\hline Cluster 1 & $\begin{array}{l}\text { Average } \\
\text { Coefficient of } \\
\text { variation } \\
\text { No units }\end{array}$ & $\begin{array}{l}5,03 \\
3,91 \\
77,73 \% \\
630\end{array}$ & $\begin{array}{l}5,12 \\
4,27 \\
83,39 \% \\
645\end{array}$ & $\begin{array}{l}3,85 \\
3,29 \\
85,45 \% \\
572\end{array}$ & $\begin{array}{l}3,62 \\
2,96 \\
81,76 \% \\
515\end{array}$ & $\begin{array}{l}5,45 \\
4,89 \\
89,72 \% \\
533\end{array}$ \\
\hline Cluster 2 & $\begin{array}{l}\text { Average } \\
\text { Coefficient } \\
\text { variation } \\
\text { No units }\end{array}$ & $\begin{array}{l}24,07 \\
7,77 \\
32,28 \% \\
130\end{array}$ & $\begin{array}{l}28,22 \\
11,52 \\
40,82 \% \\
100\end{array}$ & $\begin{array}{l}21,08 \\
7,95 \\
37,71 \% \\
131\end{array}$ & $\begin{array}{l}18,02 \\
5,30 \\
29,41 \% \\
142\end{array}$ & $\begin{array}{l}30,82 \\
10,88 \\
35,30 \% \\
98\end{array}$ \\
\hline Cluster 3 & $\begin{array}{l}\text { Average } \\
\text { Coefficient of } \\
\text { variation } \\
\text { No units }\end{array}$ & $\begin{array}{l}69,38 \\
18,12 \\
26,11 \% \\
27\end{array}$ & $\begin{array}{l}96,79 \\
14,86 \\
15,35 \% \\
10\end{array}$ & $\begin{array}{l}67,45 \\
13,36 \\
19,80 \% \\
20\end{array}$ & $\begin{array}{l}46,59 \\
12,03 \\
25,82 \% \\
29\end{array}$ & $\begin{array}{l}101,30 \\
21,75 \\
21,47 \% \\
9\end{array}$ \\
\hline
\end{tabular}

In the context of trade activity, commodity stock is the basic working tool. Its efficient management (inventory optimization) implies that customer requirements are met in the shortest possible time at the least cost of management. Even if the average storage time is low in hypermarkets-supermarkets due to the massive quantities sold, the level of stocks (in absolute value) is much higher than for small and medium retail companies. For a fair comparison of stocks of large retail companies with the stocks of small retail companies, we calculated their level at 100 lei assets held.

The percentaje of inventory to total assets $=\frac{\text { Average inventory }}{\text { Total assets }} * 100=$

$\frac{\text { Net sales } \times \text { Average inventory days }}{365 \text { days } *(\text { Long }- \text { term Assets }+ \text { Current assets })} * 100=\frac{\text { Average inventory days }}{365 \text { days }} *\left(\frac{\text { Net sales }}{\text { Total assets }}\right) * 100$

The calculations made for the seven hypermarkets-supermarkets indicate, during the 2013-2016 period, a 22\% share of inventory to total assets. 
In the case of other stores in Cluj County, the share of stocks in total assets in 20112015 is very different: approx. $30 \%$ of the studied collectivity registers stocks with a weight of over $90 \%$ (Cluster 4 ) in total assets, this being considered the most homogeneous group by the coefficient of variation $(\mathrm{Cv}=5 \%)$.

Two other groups with a share of $32 \%$ in the studied collectivity have stocks ranging between $50-77 \%$ of the total assets (Cluster No. 2 and Cluster 3).

Based on the calculations we made, we can say, that small and medium retail companies in the Cluj area (60\%) have a high share of inventory to total assets (50-90\%). The low sales, the lack of investments and the desire to provide a wide range of assortments (low inventory turnover assortments) are some causes that lead to this state. Sales growth is a desideratum of any store, but not to the detriment of profit. The main objective of any trading company is profit. The existence and competitiveness of a trading company is ultimately determined by the existence and level of profit! In order to compare the net profit with the volume of sales, we opted for the net profit margin indicator (net profit / turnover*100). It is worth mentioning that in the case of the food trade enterprises of Cluj County (Figure 4), the share of those who registered losses is higher than of those who registered profits.

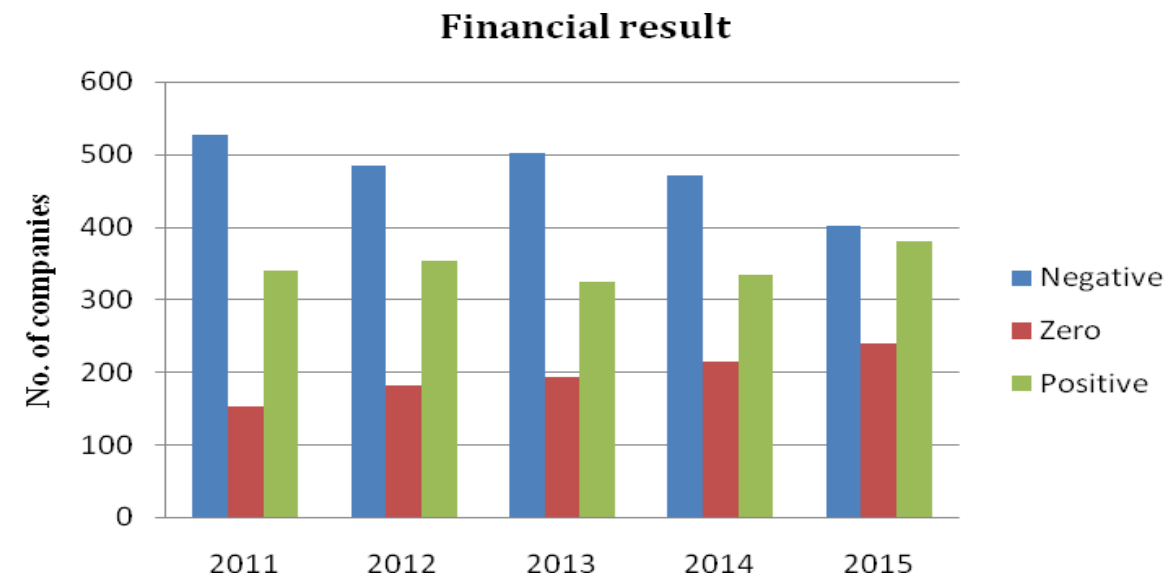

Figure 4- Financial results for food trade companies from Cluj County in 2011-2015

Source: authors' own research

Based on the net margin indicator, we can see the price, cost and profitability policies of these retail companies:

Table 5. The ratio between the annual growth of turnover and the average net margin for the studied period

\begin{tabular}{|l|l|l|l|l|l|l|l|}
\hline & Kaufland & Carrefour & Lidl & Penny & Profi & Auchan & Billa \\
\hline Net margin & $5,87 \%$ & $2,84 \%$ & $3,17 \%$ & $0,46 \%$ & $2,24 \%$ & $0,30 \%$ & $0,17 \%$ \\
\hline Asset turnover ratio & 1,38 & 1,93 & 2,62 & 4,16 & 2,90 & 1,53 & 3,51 \\
\hline Return on assets (ROA) & $8,2 \%$ & $5,5 \%$ & $8,4 \%$ & $1,9 \%$ & $6,6 \%$ & $0,4 \%$ & $0,6 \%$ \\
\hline Financial leverage & 1,80 & 2,53 & 1,83 & 3,03 & 3,99 & 1,43 & 2,05 \\
\hline Return on equity (ROE) & $14,41 \%$ & $13,66 \%$ & $15,30 \%$ & $5,78 \%$ & $27,94 \%$ & $1,18 \%$ & $1,13 \%$ \\
\hline
\end{tabular}

Source: authors' own research 
In the case of supermarkets-hypermarkets, given the low discount and low pricing policy, we find that only three supermarkets (Kaufland, Lidl, Carrefour) have a higher net margin. Kaufland has a profit of 5.7 lei for 100 lei sales and Carrefour of 2.4 lei, managing to keep its costs at a lower level (94.3 lei at Kaufland and 97.6 lei at Carrefour) than in the case of the other supermarkets. The other supermarkets have a lower margin (Auchan, Penny, Profi), with an average of 98 lei per 100 lei of sale.

PICBE | 78

According to the index of prices published by INSSE, food commodity prices in Romania decreased during the 2013-2016 period, and there is an insignificant increase in the case of non-food goods. Thus, by deduction, we can assume that this development will also apply for supermarkets. It is worth mentioning that the Auchan Romania hypermarket has registered a significant annual growth (over 10\%) in the last 5 years and still shows a loss in 2013, 2014, 2016 and a small profit in 2015, 2017.

In the case of (small and medium-sized) shops in the Cluj area, $66 \%$ are in lossmaking and only $36 \%$ have positive net margin, and $37 \%$ of them have a net margin under $2 \%$. The group with the largest concentration of stores has a net margin of $0-2 \%$.

Possible explanations for this low margin could be the high cost of goods in relation to prices, driven largely by large chain stores, low purchasing power of the population (in the case of rural shops), the supply from big chain stores and not by the manufacturer or a survival policy for a period of time through low prices, thus accepting a low margin.

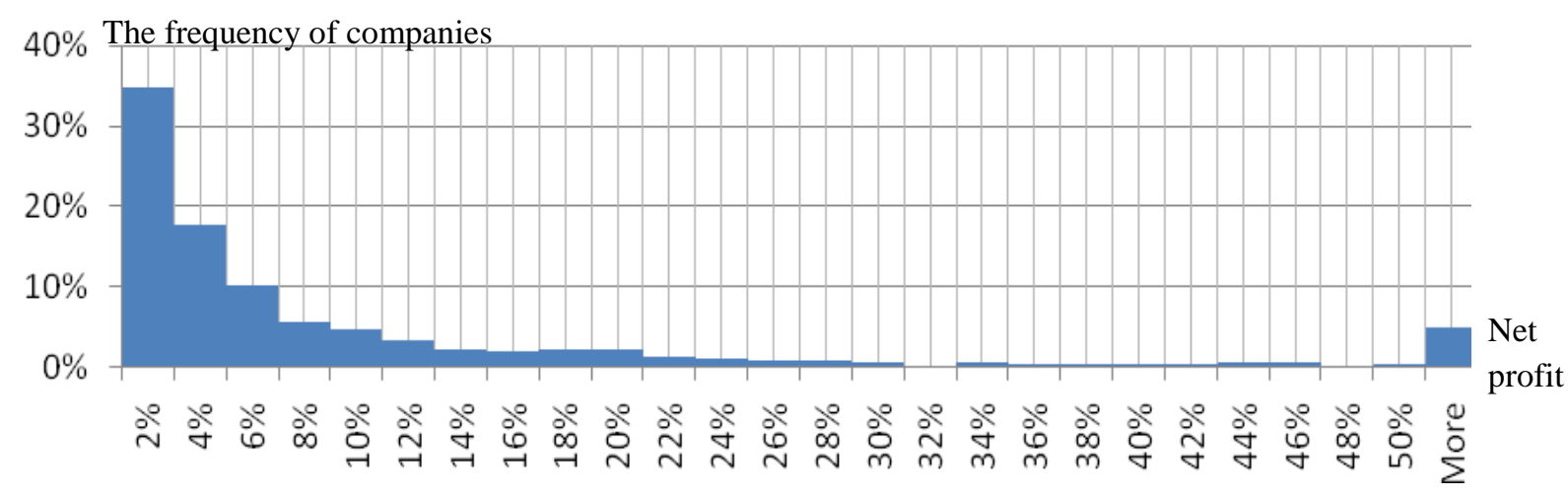

Figure 5: Distribution of net margin for stores in Cluj county (

Source : authors' own research

From the histogram we can see how asymmetric the distribution of small and medium sized businesses is, according to the net margin feature. The degree of concentration of the companies is also reflected by the average deviation coefficient Gini $=0.58$.

According to COFACE Agency in Romania, the net trade margin is 3.7\%, much higher than that of hypermarkets or most food stores in the Cluj area.

A small net margin, without multiplication by the turnover speed of assets and financial leverage, leads to dissatisfaction on the part of the shareholders and associates, due to the low profitability of joint-stocks or shares [Brezeanu P. \& Boanta R., 2017]. In the case of the Profi supermarket, even if it has a low net margin (ROS $=2.4$ ), it has the highest financial return $(\mathrm{ROE}=27 \%)$ due to the number of turnovers of total assets (No.rot $=3$ rot.), as well as the financial structure (indebtedness $=72 \%$ ). 
Looking at the financial profitability of the market sector of emerging countries, only four of the supermarkets exceed this level (8.05\% for 2016). A prudent investor considering the interest rate on government securities issued by the Ministry of Finance $(3.25 \%)$ with a maturity of 5 years will opt for investments only for the first 5 companies.

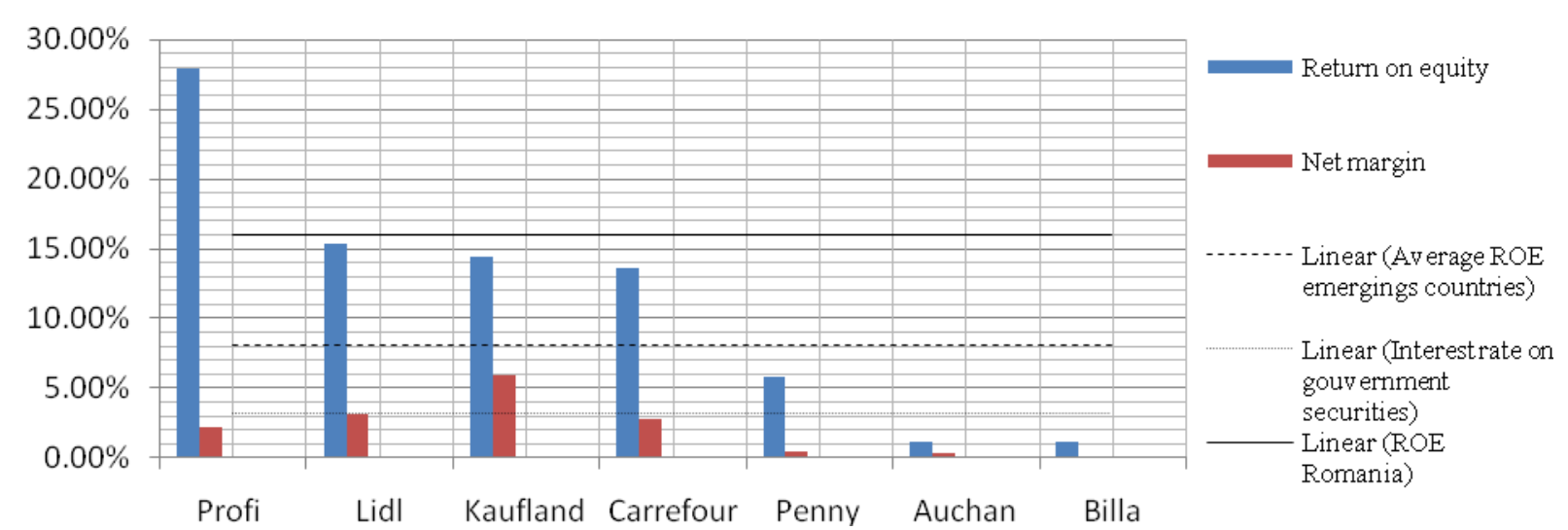

PICBE | 79

Figure 6. Decisive indicators in the investment process

Source: authors' processing of NBR balance-sheet In the studied sample, representing the Cluj area, only 370 out of 1,020 companies registera positive financial return, and $19 \%$ of them experiencea financial return ranging from 0.1 to $5 \%$.

It is worth mentioning that, within the 370 companies, the following group with a frequency of $14 \%$ (29 companies) has a financial return of $10.1-20 \%$, superior to the sector of activity.

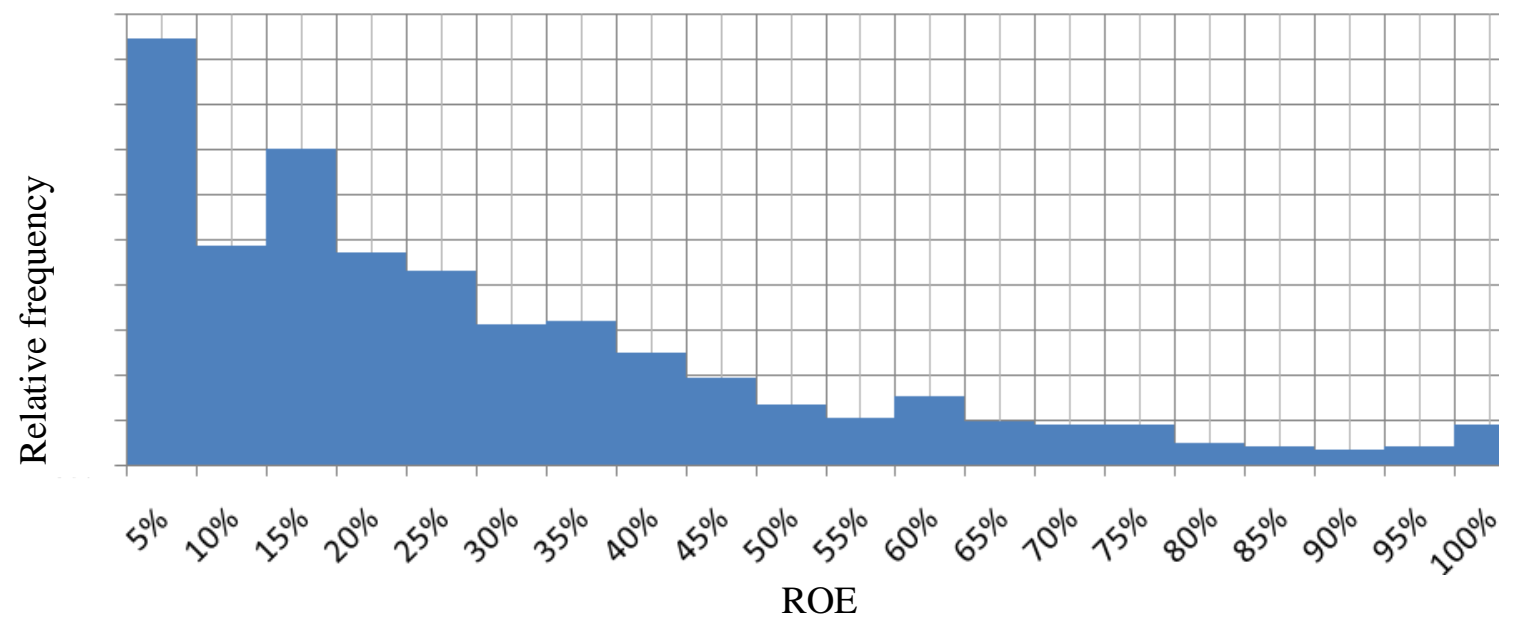

Figure 7- Distribution of stores in Cluj, by financial returns

Source: authors' processing of the data in the Statement of comprehensive income issued by the Financial Office of Cluj

Thus, $67 \%$ of the companies analyzed are loss-making and $18 \%$ of the profitable companies have a financial profitability of $0-5 \%$. The average in this case is unrepresentative given the value of the variation coefficient (89\%). 
Companies with a low profitability (low net margin) to finance their development or exploitation activity turn to indebtedness, thus exposing themselves to a high financial risk. Due to accumulated losses from previous financial years, many stores in Cluj County run on negative equity (being considered insolvent), and many among those which are profitable registera low profit (low profitability), which explains the call to indebtedness.

In order to look at the financing policy for small and medium-sized stores (Table 6), we looked at the financial autonomy indicator (ratio between equity and total funding resources). The results certify that most of Cluj's food trade companies run on debt-based financing, which results in financial risk and a risk of bankruptcy.

Table 6. Statistical characteristics of the financial autonomy indicator for the whole community and by groups

\begin{tabular}{|c|c|c|c|c|c|c|}
\hline Groups & $\begin{array}{l}\text { Statistical } \\
\text { indicator }\end{array}$ & 2011 & 2012 & 2013 & 2014 & 2015 \\
\hline $\begin{array}{l}\text { Entire } \\
\text { collectivity }\end{array}$ & $\begin{array}{l}\text { Average } \\
\text { Coefficient of } \\
\text { variation } \\
\text { No units }\end{array}$ & $\begin{array}{l}-164,98 \% \\
606,84 \\
367,82 \% \\
1.002\end{array}$ & $\begin{array}{l}-231,29 \% \\
871,35 \\
376,73 \% \\
1.003\end{array}$ & $\begin{array}{l}-270,51 \% \\
893,34 \\
330,24 \% \\
999\end{array}$ & $\begin{array}{l}-325,21 \% \\
1.011,25 \\
310,95 \% \\
992\end{array}$ & $\begin{array}{l}-348,92 \% \\
1.077,53 \\
308,81 \% \\
982\end{array}$ \\
\hline Cluster 2 & $\begin{array}{l}\text { Average } \\
\text { Coefficient of } \\
\text { variation } \\
\text { No units }\end{array}$ & $\begin{array}{l}-33,77 \% \\
99,49 \\
294,61 \% \\
905\end{array}$ & $\begin{array}{l}-70,96 \% \\
164,90 \\
232,38 \% \\
947\end{array}$ & $\begin{array}{l}-85,97 \% \\
195,56 \\
227,47 \% \\
939\end{array}$ & $\begin{array}{l}-94,78 \% \\
209,62 \\
221,16 \% \\
919\end{array}$ & $\begin{array}{l}-75,68 \% \\
179,47 \\
237,14 \% \\
877\end{array}$ \\
\hline
\end{tabular}

Source: Authors' own research

The study found that the group with the highest frequency is Group2. Due to the outliners and the high values of the coefficient of variation of Group 2 (Cluster 2), we considered regrouping necessary. Thus, we obtained more homogeneous subgroups with a more representative average (Table no. 7).

Table 7: Regrouping of Cluster 2

\begin{tabular}{|c|c|c|c|c|c|c|c|c|c|c|}
\hline & \multicolumn{2}{|l|}{2011} & \multicolumn{2}{|l|}{2012} & \multicolumn{2}{|l|}{2013} & \multicolumn{2}{|l|}{2014} & \multicolumn{2}{|l|}{2015} \\
\hline Cluster & $\begin{array}{l}\text { No. } \\
\text { elem. }\end{array}$ & $\begin{array}{l}\text { Average } \\
\text { (\%) }\end{array}$ & $\begin{array}{l}\text { No. } \\
\text { elem. }\end{array}$ & $\begin{array}{l}\text { Average } \\
\text { (\%) }\end{array}$ & No. ele & $\begin{array}{l}\text { Average } \\
(\%)\end{array}$ & $\begin{array}{l}\text { No. } \\
\text { elem. }\end{array}$ & $\begin{array}{l}\text { Average } \\
(\%)\end{array}$ & $\begin{array}{l}\text { No. } \\
\text { elem. }\end{array}$ & $\begin{array}{l}\text { Average } \\
(\%)\end{array}$ \\
\hline 1 & 44 & $-321,47$ & 18 & $-705,10$ & 14 & $-864,90$ & 13 & $-936,45$ & 14 & $-723,87$ \\
\hline 2 & 219 & 66,02 & 629 & 16,87 & 675 & 7,53 & 629 & 13,22 & 574 & 23,71 \\
\hline 3 & 177 & $-88,66$ & 67 & $-349,17$ & 62 & $-417,67$ & 65 & $-461,91$ & 62 & $-393,48$ \\
\hline 4 & 67 & $-195,26$ & 22 & $-562,37$ & 28 & $-674,19$ & 26 & $-728,90$ & 25 & $-599,68$ \\
\hline 5 & 398 & $-5,27$ & 211 & $-139,12$ & 159 & $-185,92$ & 186 & $-184,25$ & 202 & $-150,81$ \\
\hline Total & 905 & $-33,77 \%$ & 947 & $-70,96$ & 938 & $-86,73$ & 919 & $-94,78$ & 877 & $-75,68$ \\
\hline
\end{tabular}

The values of the 2015 financial autonomy indicator for the small collectivity (982 items) indicate that there is only one semi-group with a positive average value $(23 \%$ for 574 companies). Interestingly, since 2012 improvement is visible at the level of the studied subgroup. 


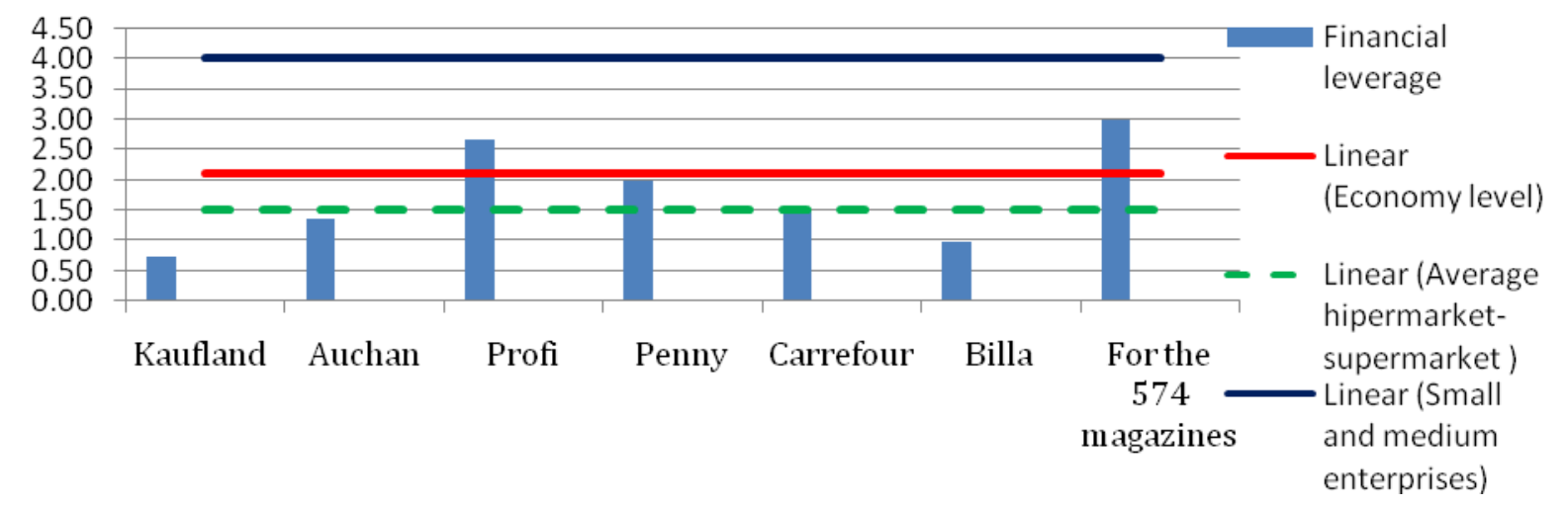

PICBE | 81

Figure 8: The financial leverage of the supermarkets in Romania compared to the 574 stores in the County of Cluj

Source : authors' own research

Due to the high profit level and reinvestment, a high degree of autonomy is observable in the case of hypermarkets-supermarkets. Only in the case of Auchan hypermarket, due to the losses registered in recent years, equity is positive because of the shared capital (shareholder contribution).

Considering the fact that the largest number of companies in Romania belongs to the category of small and medium enterprises, the financial autonomy of these companies is below 20\% (Financial leverage $=4$ ). For the entire economy, the average for all companies is slightly above $50 \%$ (Leverage $=2.1$ ). By comparing the financing of supermarkets in Romania with the financing of small shops, we find that small shops are financed in a very high proportion bydebts, as opposed to the supermarkets that are financed out of their own resources in proportion of over $50 \%$. A high degree of indebtedness reflects low solvency and a major risk of bankruptcy.

Taking into account the financial performance and resources for funding, we believe that it is important to analyze financial balances (to face current obligations and current assets), thus being able to appreciate the degree of coverage of current liabilities through liquidities resulting from the disposal of assets. The results of the analysis of the overall liquidity indicator are: Cluster no. 1, with the largest number of elements (about $85 \%$ of the collectivity), scores between 0.79 and 1.05 for this indicator and shows a low homogeneity (high variance coefficient ranging from $85.54 \%$ to $108 \%$ ). The financial balance in these stores is fragile, the working capital in some cases is positive but has low values (LG>1).

It can be suppressed in the future as a result of the unpredictable rise in debt (rising gross minimum wage, rising commodity prices due to exchange rate, etc.). In the case of these companies, given the level of this indicator and other credit worthiness indicators, there is a possibility that certain lending institutions may no longer grant them the required loans and, due to the lack of liquidity for the payment of outstanding debts, they may enter into insolvency.

As we have shown in the case of the other financial indicators, there is a small number of small and medium-sized stores (9\%) which have a very large average liquidity of 6. In the case of the seven studied supermarkets, it follows from the calculations of the 
general liquidity, which is between $0.76-1.01$, approximately equal to that of the small shops analyzed.

This is due to supplier payment policies (debts to suppliers), which account for $67 \%$ of short-term debt and inventory and receivables policies. Thus, we can deduce that the financing of the operation activity is largely due to the credit granted by suppliers.

\section{Conclusion}

The comparative study based on the five financial indicators between supermarkets hypermarkets in Romania (with superior performances) and that of small and medium retail stores in the Cluj area reflects to a certain extent the factors and causes which determine the current state, as well as the perspective for small and medium-sized stores if they do not change their strategy.

Table 8: The level of the studied financial indicators

\begin{tabular}{|c|c|c|c|}
\hline No. & Indicators & Supermarkets & $\begin{array}{l}\text { Most small and medium sized shops in } \\
\text { the Cluj area }\end{array}$ \\
\hline 1 & $\begin{array}{l}\text { Average inventory days [(Average } \\
\text { inventory/Net sale)*365 days] }\end{array}$ & $\begin{array}{l}\text { approximately } 30 \\
\text { days (one month) }\end{array}$ & $\begin{array}{l}\text { approximately } 90 \text { days }(80 \% \text { of the } \\
\text { sample studied have this average } \\
\text { storage life })\end{array}$ \\
\hline 2 & $\begin{array}{l}\text { The percentage inventory in total } \\
\text { assets [(Average inventory/Total } \\
\text { assets }) * 100]\end{array}$ & average value $22 \%$ & $\begin{array}{l}90 \%(30 \% \text { of the studied sample have } \\
\text { this value); } \\
24 \div 50 \% \text { ( } 30 \% \text { of the studied sample } \\
\text { this value) }\end{array}$ \\
\hline 3 & $\begin{array}{l}\text { Net margin [(Net profit/ net } \\
\text { sale)*100] }\end{array}$ & average value $2,5 \%$ & $\begin{array}{l}<2 \%(77 \% \text { from the studied sample } \\
\text { have negative results or a net margin } \\
\text { under } 2 \%)\end{array}$ \\
\hline 4 & $\begin{array}{l}\text { Financial leverage } \\
\text { debts/equity) } * 100]\end{array}$ & average value 1,55 & $\begin{array}{l}3,3 \text { ( } 58 \% \text { from studied sample have this } \\
\text { financial leverage, the rest of } 42 \% \text { have } \\
\text { no financial autonomy) }\end{array}$ \\
\hline 5 & $\begin{array}{l}\text { General liquidity } \\
\text { assets/debts }<1 \text { an] }\end{array}$ & between $0,76 \div 1,01$ & $\begin{array}{l}079 \div 1,05(85 \% \text { from the studied sample } \\
\text { have this level, and the rest o more } \\
\text { higher level) }\end{array}$ \\
\hline
\end{tabular}

Sources : Authors' own research

A high residence time (90 days), mainly due to reduced sales, leads to the accumulation of a large stock of goods, and without major investments, the share of these stocks in total assets will be raised (90\%). Also, low sales with a small net margin (high costs in relation to prices, dictated by large stores) will result in a low level of profit and, implicitly, low financial autonomy.

As such, funding for exploitation and investment involves a high debt leverage (financial leverage 3.3), exposing the company to far greater risks. According to the general liquidity level, both for large companies and for small companies, the financing of the operating activity (stocks and receivables) is almost entirely due to short-term liabilities of 0.79-1.05.

More specifically, in the case of hypermarkets-supermarkets, the financing of the operating activity is achieved mainly through commercial credit, while in the case of small shops, due to the lack of confidence of the suppliers, commercial credit is lower compared to other debts of less than one year.

According to the level of the five indicators, the life expectancy of many small traditional stores does not seem to be too long! However, today, small businesses are the engines of local commerce; they hire and serve the local population. Of course, we can also 
find small and medium-sized stores that thrive (as proven by the level of the financial calculation indicators), who know their clients well, communicate with them permanently (even a friendship relationship is created), offer personalized services directly from suppliers of domestic products and are located in densely populated areas (tobacco shops). According to the statement of some retailers, the key to success is the location [Kotler, 2003].

In order to dominate the market, many large companies adopt the strategy of merging and acquisition (Billa being taken over by Carrefour, Auchan merged through absorption with Real), a trend also manifested globally. This example could be taken up by small shops by creating associations, otherwise this would result in negotiations with foreign and domestic producers.

Their disappearance from the market is not yet possible because it would generate social problems, economic issues and dissatisfaction of a segment of customers who prefer to shop nearby (proximity or rural shops).

\section{References}

Agriculturae (2017): Organic and traditional products, Retrieved from: http://www.agriculturae.ro/index.php/agricultura-ecologica/produseecologice/3225-piata-produselor-ecologice-din-romania-in-2016.html , 08.11.2017

Brezeanu, P., Rodica B. (2017): The leverage effect impact between the economic \& financial flow, European Journal of Business and Social Sciences, Vol. 6, No. 02, p.p. 99-115

Drucker,F. P. (2004): Management of the future, Ed.ASAB, Bucuresti, 2004, p.p. 65

DWBI Expert Inc (2017): Retail, metrics \&KPI, Retrieved from: http://www.dwbiexpert.com/en/retail-kpi/

Fenyves, V. (2016): Az Észak-Alföldi régióban élelmiszer-kiskereskedelmi tevékenységet folytató vállalkozások pénzügyi kimutatásainak elemzése (Analysis of financial statements of businesses engaged in food retail activities in Northern Plain Region, Hungary), Habilitation dissertation, University of Debrecen, Debrecen, Hungary

Capece, G. et. al. (2010): A cluster analysis study based on profitability and financial indicators in the Italian gas retail market, Energy Policy, Volume 38, Issue 7, July 2010, pp. 3394-3402

Gordon, D. (2016): Key Financial Ratios for Retail Companies, Investopedia, 06.09.2016

Halper, E.B. (2001): Shopping center and stores leases, Law Journal Press, New York, 2001, p.p 9-36

Kotler, P. (2006): Marketing Management, Ed a 4-a, Ed. Teora, 2006, p.p 718

Lang, T. \& Heasman, M. (2004): Food wars, London, Earthscan, pp. 234-241

Law no. 321/2009, the Law on the Marketing of Food stuffs, published in the Official Gazette, Part I no. 705 of October 20, 2009

Law no. 150/2016, on amending and completing the Law no. 321/2009 on the Marketing of Food stuffs, published in the Official Gazette, Part I no. 534 of July 15, Retrieved from : www.bnr.ro/files/d/Pubs_ro/RSF/RSF2017_1.pdf

National Institute of Statistics, Statistical Yearbook 2018

Nicasio, F.\& Stanley, R. (2017):, Key Performance Indicators; 10 metrics for guiding and measuring store success, 2017,p.p 1-31, Retrived from: https://www.vendhq.com/images/university/retail-kpiguide/Key_Performance_Indicators.pdf

Press release Kaufland (2017): Romania inspires Romanians to reinvent themselves through the campaign "The New You Live Fresh", Retrieved from: https://despre.kaufland.ro/presa/comunicate-de-presa/pressedetail.y=2017.m=06.n=lansare-campanie-noul-tu 